\title{
KARAKTERISTIK OSEANOGRAFIS TELUK SENGGRONG BANYUWANGI
}

\section{OCEANOGRAPHIC CHARACTERISTICS OF SENGGRONG BAY BANYUWANGI}

\author{
Bambang Sukresno Denny Wijaya Kusuma Dinarika Jatisworo Eko Susilo \& Komang Iwan Suniada
}

\author{
Balai Riset dan Observasi Laut, Kementerian Kelautan dan Perikanan \\ Desa Perancak, Jembrana, Bali, Telp 0365.44266, Fax 0365.44278 \\ e-mail : bambang_sukresno@yahoo.com
}

Diterima tanggal: 14 November 2018 ; diterima setelah perbaikan: 29 November 2019 ; Disetujui tanggal: 3 Desember 2019 DOI: http://dx.doi.org/10.15578/jkn.v14i3.7247

\begin{abstract}
ABSTRAK
Penelitian ini ditujukan untuk mengetahui karakteristik oseanografis teluk Senggrong. Data yang digunakan meliputi suhu permukaan laut, konsentrasi klorofil-a, salinitas dan $\mathrm{pH}$ baik musim barat maupun musim timur. Data time series suhu permukaan laut dan klorofil-a menggunakan data dari satelit Aqua dan Terra dengan sensor Moderate Resolution Imaging Spectroradiometer (MODIS) tahun 2007 hingga 2018. Data insitu teluk Senggrong diperoleh dari pengukuran langsung yang dilakukan pada April dan September dengan menggunakan Water Quality checker (WQC).Untuk menampilkan distribusi spasial masing-masing variabel dilakukan interpolasi Krigging. Hasil penelitian menunjukan bahwa karakteristik oseanografis teluk Senggrong dipengaruhi oleh perubahan musim baik musim barat maupun musim timur. Suhu permukaan laut pada musim barat relatif lebih tinggi dibandingkan pada musim timur. Konsentrasi klorofil-a pada musim barat lebih rendah daripada musim timur.Salinitas pada musim barat lebih rendah dibandingkan pada musim timur, sedangkan $\mathrm{pH}$ pada musim barat lebih tinggi daripada musim timur. Pada musim barat teluk Senggrong memiliki suhu permukaan laut antara $28,1^{\circ}-31,6^{\circ} \mathrm{C}$, konsentrasi klorofil-a sekitar $0,2 \mathrm{mg} / \mathrm{m}^{3}-0,5 \mathrm{mg} / \mathrm{m}^{3}$, salinitas sebesar $32 \mathrm{ppm}-33 \mathrm{ppm}$ dan $\mathrm{pH}$ berkisar 8,4 - 8,7. Sedangkan pada musim timur suhu permukaan laut berkisar antara $24,9^{\circ}-30,7^{\circ}$, konsentrasi klorofil-a sebesar $0,1 \mathrm{mg} / \mathrm{m}^{3}-3,5 \mathrm{mg} / \mathrm{m}^{3}$, salinitas antara 34-35 ppm dan $\mathrm{pH}$ sekitar 7,5 - 8,3.
\end{abstract}

Kata kunci : Suhu permukaan laut, klorofil-a, pH, salinitas, teluk Senggrong.

\section{ABSTRACT}

This study was aimed to get further information about oceanographic characteristics of Senggrong bay. The used data consist of sea surface temperature, chlorophyll-a concentration, salinity and $\mathrm{pH}$ in the northwest and southeast monsoon. Time series data of sea surface temperature and chlorophyll-a during 2007 - 2018 were obtained from Moderate Resolution Imaging Spectroradiometer (MODIS) on board MODIS and Terra satellite. Insitu measurements were conducted in April and September using Water Quality Checker (WQC). Spatial distribution of each variable was displayed by krigging interpolation process. Results of the study show that the oceanographic characteristics of Senggrong bay were influenced by northwest and southeast monsoon. Sea surface temperature of northwest monsoon was higher than that of southeast monsoon. Chlorophyll-a concentration of northwest monsoon was lower than that of southeast monsoon. Salinity of northwest monsoon was lower than that of southeast monsoon, while pH of northwest monsoon was higher than that of southeast monsoon. During northwest monsoon Senggrong bay was characterized by sea surface temperature about 28.1 to $31.6^{\circ} \mathrm{C}$, chlorophyll-a concentration in the range of $0.2-0.5 \mathrm{mg} / \mathrm{m}^{3}$, salinity around $32-33 \mathrm{ppm}$ and pH about 8.4-8.7, while during southeast monsoon sea surface temperature was about 24.9 to $30.7^{\circ} \mathrm{C}$, chlorophyll-a concentration in the range of $0.1-3.5 \mathrm{mg} / \mathrm{m}^{3}$, salinity around $34-35 \mathrm{ppm}$ and $\mathrm{pH}$ about $7.5-8.3$

Keywords: Sea surface temperature, chlorophyll-a, pH, salinity, Senggrong bay. 


\section{PENDAHULUAN}

Teluk Senggrong merupakan bagian dari selat Bali yang berada di pesisir kabupaten Banyuwangi dengan lokasi sekitar $114^{\circ} 27^{\prime} 6,67^{\prime \prime} \mathrm{BT}, \quad 8^{\circ} 37^{\prime} 44,47^{\prime}$ 'LS. Secara administratif teluk Senggrong merupakan wilayah kecamatan Tegal Dlimo dan berbatasan dengan taman nasional Alas Purwo. Karakteristik oseanografis selat Bali yang memiliki korelasi dengan siklus musim baik musim barat (northwest monsoon) pada bulan Desember hingga Maret maupun musim timur (southeast monsoon) pada bulan Juni hingga September (Susilo, 2015). Lebih jauh Hendiarti (2015), menjelaskan bahwa karakteristik oseanografis akan mempengaruhi kelimpahan ikan pelagis, selain itu juga dipengaruhi oleh fenomena oseanografis seperti upwelling, throughflow, coastal discharge dan el nino. Gaol et al (2010) menemukan bahwa selain dipengaruhi oleh siklus musim timur dan musim barat, kondisi oseanografi selat Bali khususnya konsentrasi klorofil-a juga dipengaruhi oleh fenomena Dipole Mode.

Secara umum selat Bali memiliki batimetri yang relatif dangkal di bagian utara dekat dengan Gilimanuk, namun semakin ke selatan hingga ke samudera Hindia batimetrinya semakin dalam, sehingga dapat dikatakan bahwa pertukaran massa air antara selat Bali dengan Laut Bali di bagian utara cenderung merupakan massa air permukaan (Priyono et al, 2008).

Khasanah et al (2013), mendapati bahwa selat Bali memiliki kandungan oksigen yang lebih tinggi pada musim peralihan II dibandingkan pada musim barat, hal ini dimungkinkan oleh adanya fotosintesis fitoplankton serta difusi oksigen dari udara.

Meskipun luasan teluk Senggrong relatif kecil dibandingkan dengan selat Bali namun daerah tersebut merupakan suatu kawasan penting bagi nelayan, khususnya yang mengoperasikan alat tangkap bagan (Aliyubi et al, 2015 dan Himelda et al, 2011). Disamping itu teluk Senggrong juga merupakan satu dari lima daerah penangkapan ikan lemuru di selat Bali, dimana distribusi spasialnya dipengaruhi oleh Suhu Permukaan Laut (SPL), salinitas dan klorofil-a (klor-a) (Setyohadi, 2012). Oleh karena itu maka informasi mengenai karakteristik oseanografis yang lebih detil di teluk Senggrong penting untuk diteliti. Penelitian ini bertujuan untuk mengetahui karakteristik oseanografis teluk senggrong yang terdiri atas SPL, klor-a, salinitas dan $\mathrm{pH}$ baik musim barat maupun musim timur.

\section{BAHAN DAN METODE}

Karakteristik SPL dan Klor-a di teluk Senggrong dan selat Bali dianalisis dengan mengunakan data time series pada periode yang cukup panjang. Dalam penelitian ini digunakan data dari satelit tahun 2007 hingga 2018. Penggunaan data satelit dilakukan karena kemampuanya dalam menyediakan data dengan cakupan wilayah yang luas serta resolusi spasial dan temporal yang tinggi.

Data satelit yang digunakan adalah data dari satelit Aqua dan Terra yang membawa sensor Moderate Resolution Imaging Spectroradiometer (MODIS). Satelit tersebut mengindera permukaan bumi pada 36 saluran spektral pada rentang panjang gelombang 0.4 $\mu \mathrm{m}$ hingga $14.4 \mu \mathrm{m}(\mathrm{NASA}, 2018)$.

Data SPL yang digunakan adalah level 3 bulanan dengan resolusi spasial $4 \mathrm{~km}$ yang merupakan hasil pemrosesan saluran $22(3,959 \mu \mathrm{m})$ dan $23(4,050 \mu \mathrm{m})$ dengan menggunakan algoritma SST4 (Shortwave Sea Surface Temperature). Data klor-a yang digunakan juga data satelit level 3 bulanan dengan resolusi spasial $4 \mathrm{~km}$ yang di proses dengan algoritma untuk klor-a, didasarkan pada model semi-analitikal dan bio-optikal dari pantulan penginderaan jauh (Rrs) pada panjang gelombang antara $440 \mathrm{~nm}$ hingga $670 \mathrm{~nm}$. Data diunduh dari website https://oceancolor.gsfc.nasa.gov/ cgi/13.

Data insitu teluk Senggrong diperoleh dari pengukuran langsung yang dilakukan pada April dan September dengan menggunakan Water Quality Checker (WQC). Data yang diukur meliputi data SPL, klor-a, salinitas dan $\mathrm{pH}$. Hasil pengukuran lapangan kemudian diproses lebih lanjut dengan interpolasi krigging sehingga bisa menampilkan distribusi spasial masing-masing variabel.

\section{HASIL DAN PEMBAHASAN}

Untuk menganalisis karakteristik oseanografis teluk senggrong maka perlu dilihat terlebih dahulu kondisi selat Bali secara umum, sehingga dapat diketahui apakah teluk senggrong memiliki karakteristik yang berbeda atau sama. SPL selat bali mengalami fluktuasi musiman dimanasecara umum SPL pada musim barat lebih tinggi dibandingkan pada musim timur. Sebagaimana pada Gambar 1.

Gambar 1.a. menunjukan distribusi spasial SPL di selat bali pada musim barat (data bulan Juni - Agustus), 



Gambar 1. SPL selat Bali musim barat (a) dan musim timur (b) berdasarkan rata rata dari tahun 2007 - 2018.

Figure 1. SST of Bali strait during northwest monsoon (a) and southeast monsoon (b) based on time series data average during 2007-2018.

hampir seluruh wilayah selat bali memiliki SPL yang relatif hangat terlihat dengan warna kuning hingga merah yang berkisar antara $27^{\circ}$ hingga $31^{\circ} \mathrm{C}$. Wilayah yang relatif dingin hanya terlihat di bagian utara terlihat dengan warna biru, yang merupakan mulut selat Bali yang berbatasan dengan laut Bali.Sebaliknya pada musim timur sebagaimana pada Gambar 1.b. terlihat bahwa selat bali didominasi SPL yang relatif dingin yang ditandai dengan warna biru yang berkisar antara $24^{\circ} \mathrm{C}$ hingga $28^{\circ} \mathrm{C}$. Kondisi ini sesuai dengan penelitian Ridha et al (2013), yang menyatakan bahwa SPL selat bali pada musim barat relatif lebih hangat berkisar antara $27^{\circ} \mathrm{C}$ hingga $32^{\circ} \mathrm{C}$, sedangkan pada musim timur berkisar antara $22^{\circ} \mathrm{C}$ hingga $28^{\circ} \mathrm{C}$. Hal yang sama juga dinyatakan oleh Susilo (2015), dimana SPL selat Bali bervariasi berdasarkan pada musim. Bahkan lebih jauh Rintaka et al (2015), menjelaskan bahwa SPL di selat Bali pada musim timur dipengaruhi oleh indirect upwelling karena adanya ekman upwelling yang terjadi di perairan selatan Jawa hingga Nusa Tenggara sehingga SPL selat Bali di Bagian selatan relatif lebih dingin dibandingkan bagian utara.
Data SPL rata-rata bulanan selat Bali dari tahun 2007 hingga 2018 menunjukan adanya fluktuasi yang sangat bervariasi sebagaimana terlihat pada Gambar 2. Secara umum SPL mengalami peningkatan pada musim barat dan mencapai puncaknya pada FebruariMaret dan kemudian mengalami penurunan pada musim timur hingga mencapai suhu terendah pada Agustus-September. Namun demikian pada periode tertentu terdapat kondisi yang ekstrim dimana SPL di selat Bali jauh lebih tinggi dibandingkan tahun yang lainnya,misalnya SPL pada 2010 dan 2016.

Secara lebih detil anomali SPL rata-rata bulanan di selat Bali disajikan pada Gambar 3. SPL dengan rata-rata bulanan lebih rendah dari kondisi normal terlihat pada tahun 2007, 2008,2011, 2012 dan 2015. Sebaliknya SPL dengan rata-rata bulanan lebih tinggi dari kondisi normal didapati pada tahun 2010, 2013 dan 2016.

Anomali SPL di selat bali dimungkinkan karena adanya pengaruh fenomena Indian Ocean Dipole Mode (IOD). Yuniarti et al (2013), menyatakan bahwa IOD positif

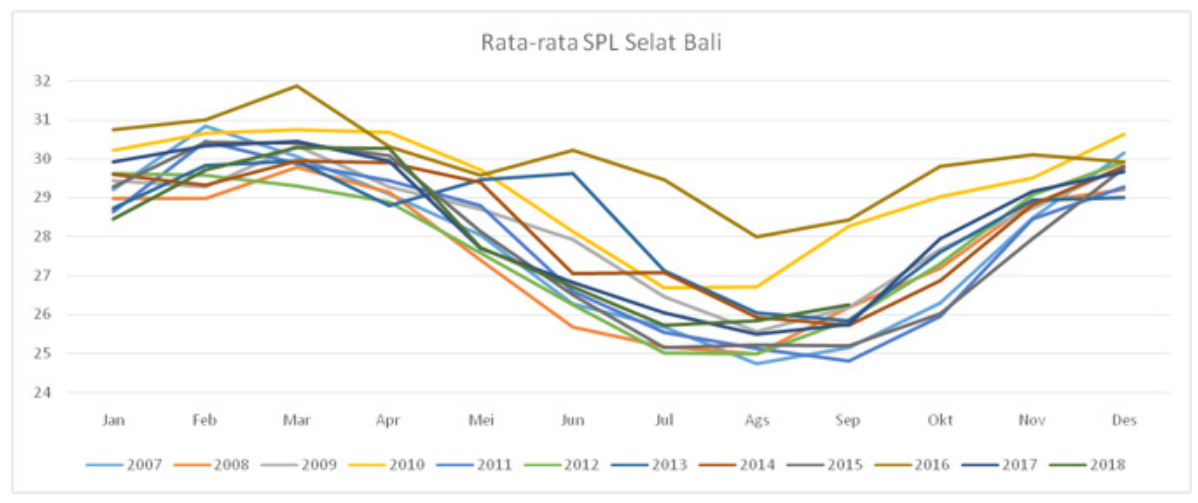

Gambar 2. Variabilitas SPL selat Bali rata-rata bulanan dari tahun 2007 - 2018.

Figure 2. monthly average of SST in Bali strait during 2007 - 2018. 


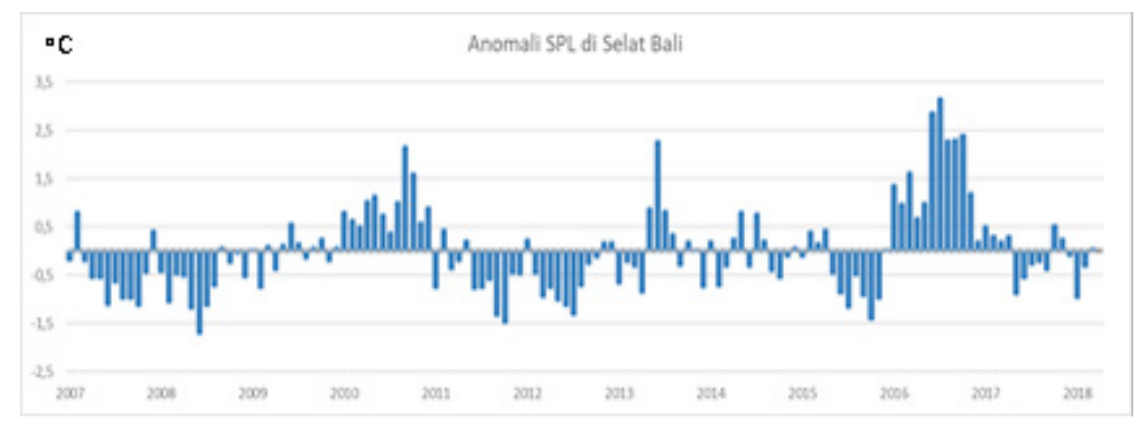

Gambar 3. Anomali SPL selat Bali dari tahun 2007 - 2018.

Figure 3. SST anomaly of Bali strait during 2007-2018.

yang ditandai dengan Indeks Dipole Mode (DMI) tinggi berkorelasi dengan naiknya intensitas upwelling di perairan selatan Jawa sehingga menyebabkan SPL menjadi lebih dingin dan mempemgaruhi SPL di selat Bali. Lebih jauh Sartimbul et al (2010), menemukan bahwa selain karena pengaruh IOD, penurunan SPL di selat Bali juga dipengaruhi oleh el nino southern oscillation (ENSO), dimana pada periode ENSO positif atau el nino maka SPL di selat Bali menjadi relatif lebih dingin dibandingkan periode ENSO normal.

Berbanding terbalik dengan SPL, konsentrasi klor-a di selat Bali pada musim barat lebih rendah dibandingkan pada musim timur. Terlihat pada Gambar 4.a. dimana klor-a di selat Bali pada musim barat secara umum tidak lebih dari $0,5 \mathrm{mg} / \mathrm{m}^{3}$, meskipun di beberapa tempat menunjukan konsentrasi klor-a yang sedikit lebih tinggi seperti di bagian selatan dan di bagian barat. Sedangkan pada musim timur pada Gambar 4.b. klor-a jauh lebih tinggi dibandingkan musim barat. Secara umum konsentrasi klor-a pada musim timur lebih dari $1 \mathrm{mg} / \mathrm{m}^{3}$, bahkan di sekitar pantai baik di bagian pulau Bali maupun di bagian pulau Jawa, konsentrasi klor-a berkisar antara $1 \mathrm{mg} / \mathrm{m}^{3}$ hingga $2 \mathrm{mg} / \mathrm{m}^{3}$, meskipun di bagian utara tetap menunjukan konsentrasi klor-a yang rendah.

Gambar 5. menunjukan siklus musiman klor-a di selat Bali. Pada musim barat terutama pada bulan Desember hingga Februari klor-a mengalami penurunan hingga kurang dari $0,5 \mathrm{mg} / \mathrm{m}^{3}$, sebaliknya pada musim timur khususnya bulan Juni hingga Agustus klor-a mengalami peningkatan. Perbandingan klor-a antar tahunan menunjukan adanya variabilitas klor-a dari tahun 2007 hingga 2018. Pada musim yang sama ternyata konsentrasi klor-a pada tahun yang berikutnya mengalami perbedaan. Misalnya pada 2010 dan 2016 dimana konsentrasi klor-a di selat Bali lebih rendah daripada tahun-tahun lainnya, hal ini berkaitan dengan tingginya SPL pada tahun yang sama. a)

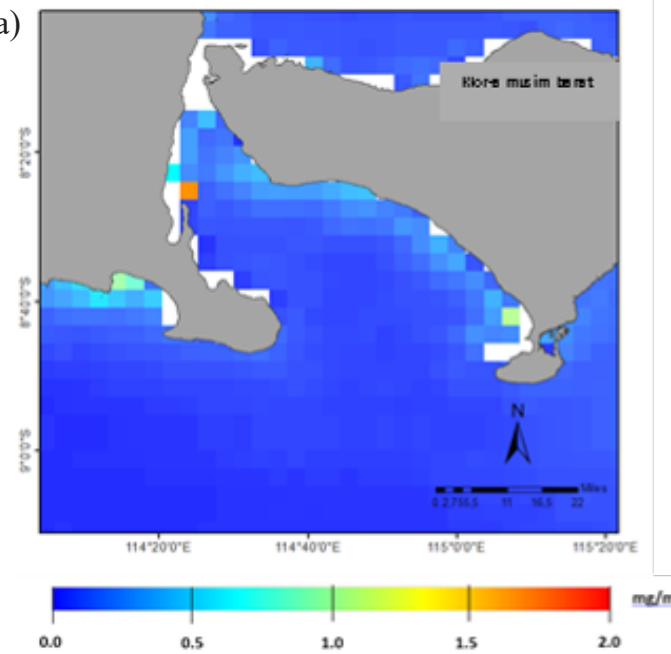



Gambar 4. Klor-a selat Bali musim barat (a) dan musim timur (b) berdasarkan rata rata dari tahun 2007 hingga 2018. Figure 4. Chlorophill-a consentration of Bali strait during northwest monsoon (a) and southeast monsoon (b) based on time series data average during 2007-2018.

JURNAL KELAUTAN NASIONAL, Vol. 14, No 3, Desember 2019, Hal. 191-200 




Gambar 5. Variabilitas klor-a selat Bali rata-rata bulanan dari tahun 2007 hingga 2018.

Figure 5. monthly average of chlorophyl-a in Bali strait during 2007 - 2018.

Sartimbul et al (2010), menyatakan bahwa konsentrasi klor-a di selat Bali mengalami variabilitas berdasarkan musim, dimana pada musim barat klo-a relatif lebih rendah dibandingkan pada musim timur. Lebih jauh Rintaka et al (2015), menemukan bahwa konsentrasi klor-a di selat Bali bervariasi berdasarkan kedalaman. Konsentrasi klor-a yang tinggi ditemukan pada kedalaman 20m-30m. Tingginya konsentrasi klor-a di selat Bali dimungkinkan karena adanya proses upwelling di bagian selatan selat Bali yang merupakan satu rangkaian dengan upwelling di selatan Jawa hingga Nusa Tenggara.

Gambar 6. menunjukan adanya anomali konsentrasi klor-a dari tahun 2007 hingga 2018 dimana klor-a mengalami penurunan pada tahun 2010, 2013 dan 2016. Semantara pada tahun 2007, 2008, 2011, 2012, 2015 dan 2017 mengalami peningkatan. Hal ini berbanding terbalik dengan anomali SPL pada tahun yang sama.

Anomali Klor-a di selat bali erat kaitannya dengan fenomena IOD. Pada saat terjadi dipole mode positif maka intensitas upwelling meningkat sehingga nutrien dari lapisan air yg lebih dalam terangkat ke permukaan dan menyebabkan konsentrasi klor-a meningkat termasuk di selat Bali ( Gaol et al., 2010). Selain dipengaruhi oleh IOD, konsentrasi klor-a di selat Bali juga dipengaruhi oleh ENSO dimana ketika indeks Nino 3.4 menunjukan nilai positif (el nino) maka perairan selatan Jawa hingga Nusa Tenggara termasuk selat Bali mengalami penurunan karena meningkatnya intensitas upwelling.

SPL dan klor-a memiliki korelasi yang tinggi dengan kondisi berbanding terbalik, dimana pada saat SPL rendah maka klor-a justru tinggi, demikian juga sebaliknya pada saat SPL tinggi justru Klor-a rendah sebagaimana terlihat pada Gambar 7. SPL mencapai puncak tertingginya sekitar bulan Maret-April dan terendah pada bulan Agustus-September, sedangkan Klor-a pada bulan Maret-April justru konsentrasinya rendah, sedangkan pada bulan Agustus - September memiliki konsentrasi tinggi.

Berdasarkan pada variabilitas SPL dan klor-a selat Bali maka perlu dilakukan analisis yang lebih detil mengenai kondisi oseanografis teluk Senggrong yang merupakan bagian dari selat Bali. Oleh karena itu maka dilakukan pengukuran data insitu pada bulan April dan September yang merupakan puncak tertinggi SPL dan klor-a. Pengukuran dilakukan di teluk Senggrong pada 14 stasiun pengukuran sebagaimana pada.



Gambar 6. Anomali SPL selat Bali dari tahun 2007 hingga 2018.

Figure 6. Chlorophyl-a anomaly of Bali strait during 2007-2018. 


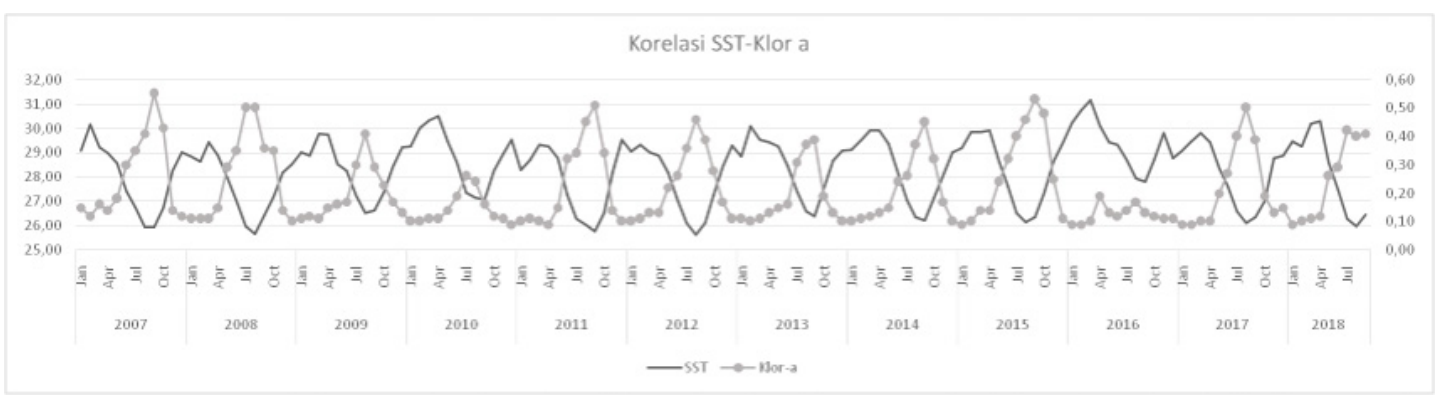

Gambar 7. Korelasi SPL dan klor-a di selat Bali.

Figure 7. Corellation of SST and chlorophyl-a in Bali strait.

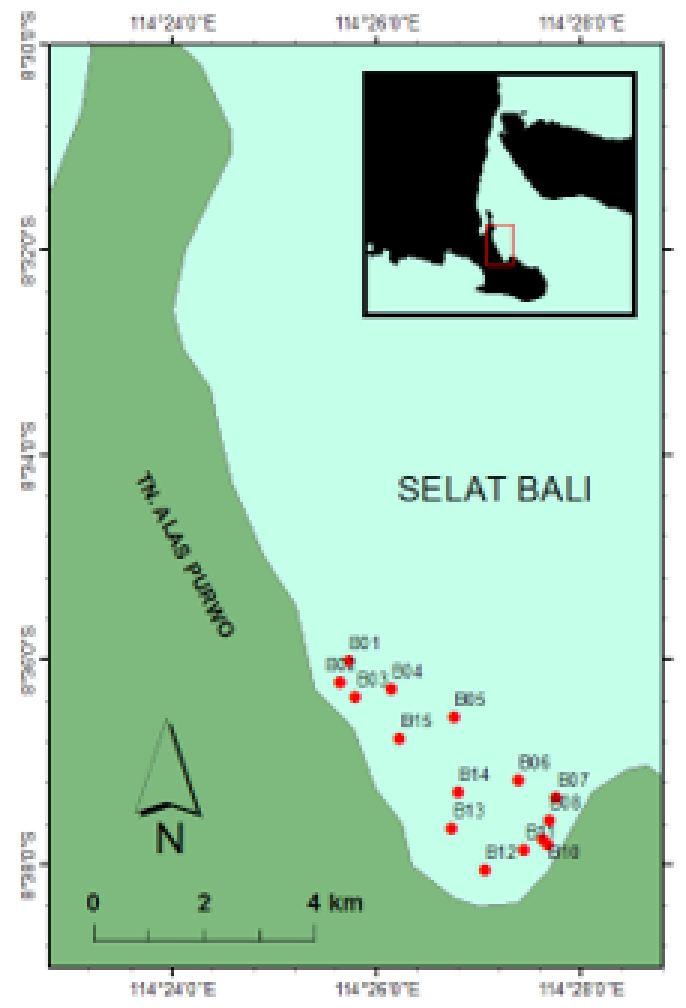

Gambar 8. Stasiun pengukuran data oseanografi di teluk Senggrong.

Figure 8. Senggrong bay oceanographic insitu measurement station.

Gambar 10.a. menunjukan distribusi spasial konsentrasi klor-a pada bulan April. Konsentrasi klor-a bervariasi dari utara ke salatan dimana bagian utara memiliki klor-a sekitar $0,5 \mathrm{mg} / \mathrm{m}^{3}$, semakin ke selatan konsentrasi klor-a di teluk Senggrong semakin kecil hingga $0,2 \mathrm{mg} / \mathrm{m}^{3}$. Berbeda jauh dengan bulan April, konsentrasi klor-a pada bulan September sangat tinggi hingga mencapai lebih dari $3 \mathrm{mg} / \mathrm{m}^{3}$ sebagaimana pada Gambar 10.b.Distribusi spasial pada bulan September didominasi oleh Konsentrasi klor-a yang rendah di bagian barat sekitar $0,1 \mathrm{mg} / \mathrm{m}^{3}$ dan ketimur semakin tinggi hingga lebih dari $3,5 \mathrm{mg} / \mathrm{m}^{3}$. Secara umum dapat dikatakan bahwa konsentrasi klor-a di teluk Senggrong memiliki variabilitas yang sama dengan selat Bali baik musim barat maupun musim timur.

Salinitas merupakan salah satu faktor penting dalam penilaian kualitas perairan. Affan (2012), menggunakan salinitas sebagai salah satu faktor utama dalam penentuan lokasi yang sesuai untuk budidaya ikan dengan wahana Keramba Jaring Apung (KJA) di perairan Bangka Tengah. Perairan yang dianggap sesuai untuk budidaya adalah yang memiliki salinitas antara 31-35 ppm. Sediadi (2004), melakukan analisis salinitas di laut Banda. Dari penelitian tersebut ditemukan bahwa salinitas mempunyai korelasi yang sangat kuat dengan suhu laut yaitu sebesar $84,1 \%$. 
a)



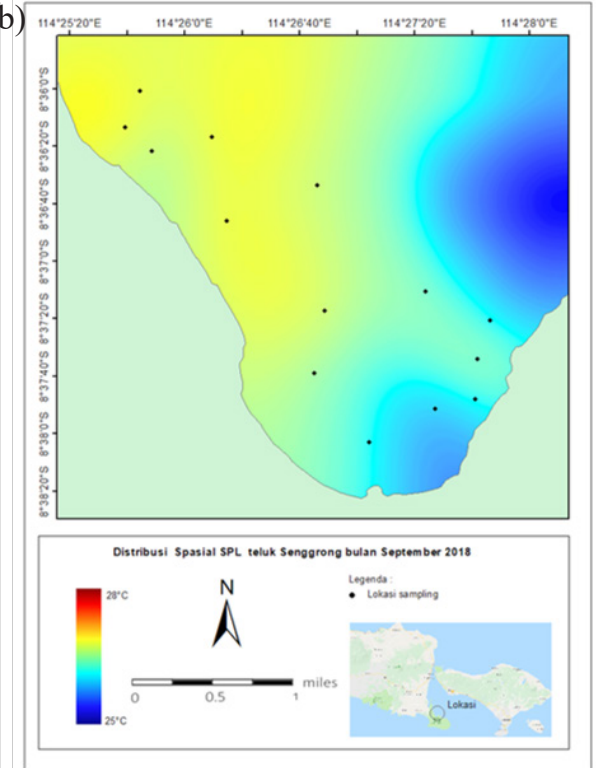

Gambar 9. Distribusi spasial SPL di teluk Senggrong pada bulan April (a) dan bulan September (b).

Figure 9. Spatial distribution of SST in Senggrong bay during April (a) and September (b).

Selain memiliki korelasi dengan suhu laut, salinitas juga memiliki korelasi yang kuat terhadap fenomena ENSO dan IOD. Grunseich et al (2011), menemukan bahwa pada saat terjadi IOD positif, salinitas di perairan barat pulau Sumatera mengalami peningkatan sebagai respons atas meningkatnya intensitas upwelling. Kondisi yang sama juga terjadi pada saat el nino. Selain itu salinitas juga memiliki kaitan yang erat dengan Indonesian Through Flow (ITF) yaitu suatu sistem transport yang membawa massa air dari samudera pasifik menuju samudera Hindia yang memiliki suhu air yang dingin dan salinitas yang rendah (Gordon, 2005).

Salinitas di selat Bali pada musim timur lebih tinggi dibandingkan dengan pada musim barat, hal ini karena terjadinya inderict upwelling yang dipicu oleh upwelling di selatan Jawa hingga Nusa Tenggara termasuk perairan selatan Bali yang ditandai dengan massa air dengan suhu yang lebih rendah dibandingkan suhu air di sekitarnya (Rintaka et al, 2015). Lebih jauh Sartimbul et al (2010), menyatakan bahwa salinitas a)

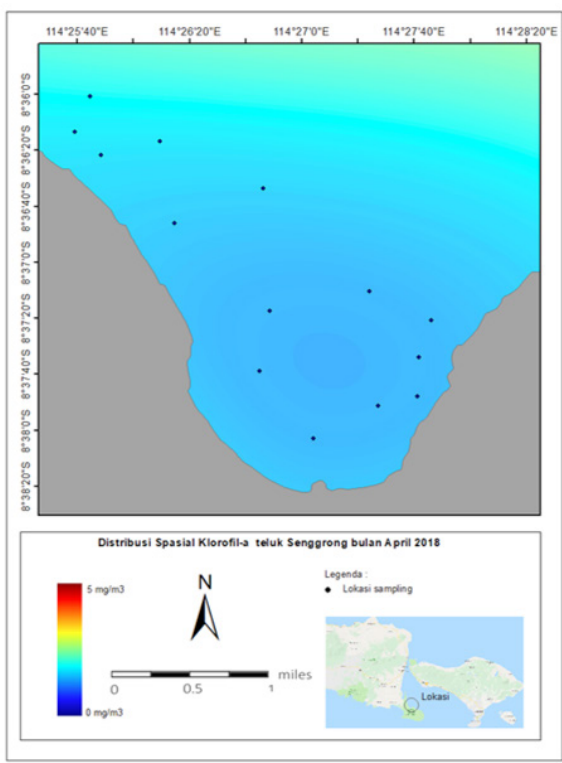

b)



Gambar 10. Distribusi spasial klor-a di teluk Senggrong pada bulan April (a) dan bulan September (b). Figure 10. Spatial distribution of chlorophyll-a in Senggrong bay during April (a) and September (b). 
a)



b)

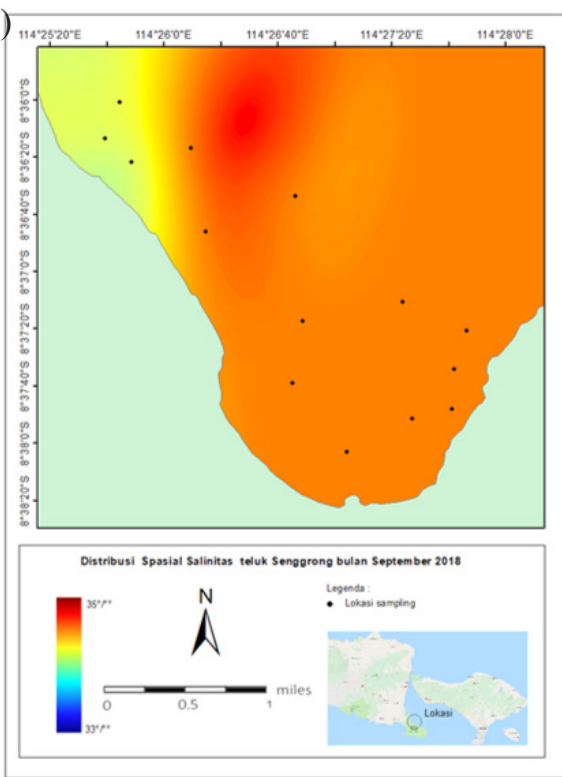

Gambar 11. Distribusi spasial salinitas di teluk Senggrong pada bulan April (a) dan bulan September (b).

Figure 11. Spatial distribution of salinity in Senggrong bay during April (a) and September (b).

a)

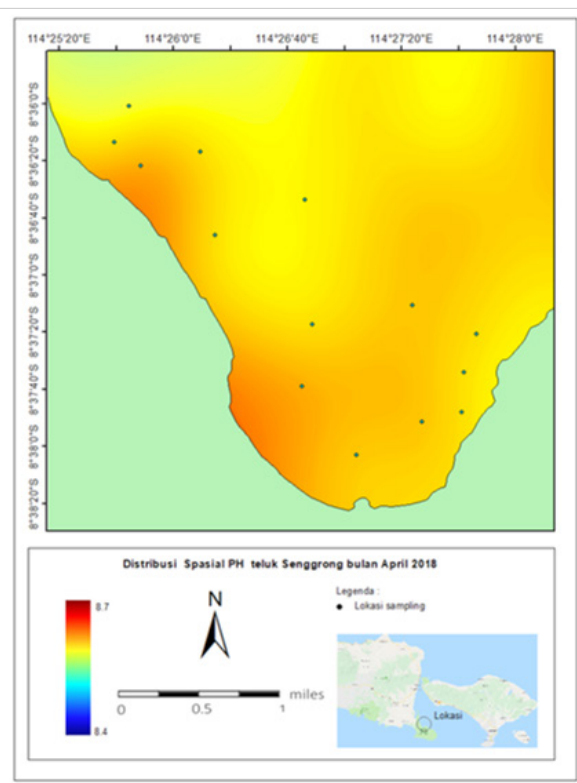

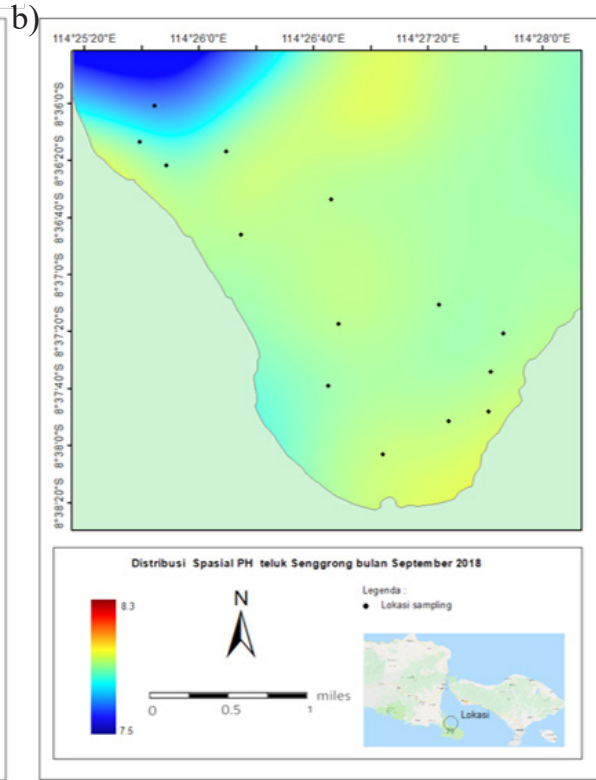

Gambar 12. Distribusi spasial PH di teluk Senggrong pada bulan April (a) dan bulan September (b).

Figure 12. Spatial distribution of pH in Senggrong bay during April (a) and September (b).

selat Bali mengalami penurunan pada musim barat dan mencapai salinitas terendah pada bulan DesemberJanuari.

Dari data pengukuran yang dilakukan pada bulan April 2018 terlihat bahwa salinitas air di teluk Senggrong relatif rendah dibandingkan pada September 2018. Salinitas pada bulan April berkisar antara $32 \mathrm{ppm}$ hingga 33 ppm dengan distribusi spasial yang bervariasi dimana di bagian selatan teluk memiliki salinitas yang relatif rendah tetapi berbatasan langsung dengan salinitas yang lebih tinggi di bagian barat sebagaimana pada Gambar 11.a. Berbeda halnya dengan bulan September dimana hampir seluruh wilayah teluk Senggrong dicirikan dengan salinitas yang tinggi berkisar antara 34 ppm hingga 35 ppm dengan distribusi spasial yang hampir merata kecuali di bagian barat yang relatif sedikit lebih rendah sebagaimana pada Gambar 11.b. 
Parameter oseanografis yang juga penting dalam penilaian kualitas air adalah pH. Safitri \& Putri (2013), menyatakan bahwa perairan Indonesia secara umum memiliki $\mathrm{pH}$ antara 7,6 - 8,3 atau bersifat basa. $\mathrm{pH}$ air laut di Indonesia secara tidak langsung dipengaruhi oleh perubahan musim melalui mekanisme transport massa air dan variabilitas intensitas curah hujan (Rizki et al, 2015). Rukminasari et al (2014), mengatakan bahwa perubahan sedikit saja pada $\mathrm{pH}$ suatu perairan laut akan mempengaruhi kehidupan organisme yang ada didalamnya. Lebih jauh Rochyatun et al (2010), menggunakan $\mathrm{pH}$ sebagai indikator pencemaran air oleh logam berat, dimana perairan yang terkontaminasi logam berat diindikasikan dengan $\mathrm{pH}$ yang relatif tinggi sekitar 7,40 hingga 8,59.

pH di teluk Senggrong pada bulan April 2018 cenderung lebih tinggi dibandingkan pada bulan September 2018. Pada bulan April seperti pada Gambar 12.a pH berkisar antara 8,4 hingga 8,7, sementara pada bulan September sebagaimana pada Gambar 12.b pH berkisar antara 7,5 hingga 8,3. Baik pada bulan April maupun September $\mathrm{pH}$ di teluk Senggong memiliki distribusi spasial yang hampir sama yaitu lebih tinggi di bagian selatan dan semakin menurun di sebelah utara.

\section{KESIMPULAN DAN SARAN}

Karakteristik oseanografi teluk Senggrong dipengaruhi oleh perubahan musim baik musim barat maupun musim timur. SPL pada musim barat relatif lebih tinggi dibandingkan pada musim timur. Konsentrasi klor-a berbanding terbalik dengan SPL dimana pada musim barat ketika SPL relatif tinggi ternyata klor-a justru memiliki konsentrasi rendah, sebaliknya pada musim timur ketika SPL rendah maka klor-a tinggi. Disisi lain salinitas pada musim barat lebih rendah dibandingkan pada musim timur, Sedangkan $\mathrm{pH}$ pada musim barat lebih tinggi daripada musim timur. Secara umum SPL dan klor-a di teluk Senggrong memiliki variabilitas musiman yang sama dengan selat Bali.

\section{DAFTAR PUSTAKA}

Affan, J. M. (2012). Identifikasi lokasi untuk pengembangan budidaya keramba jaring apung (KJA) berdasarkan faktor lingkungan dan kualitas air di perairan pantai timur Bangka Tengah. DEPIK Jurnal Ilmu-Ilmu Perairan, Pesisir dan Perikanan, 1(1).

Aliyubi, F. K., Boesono, H., \& Setiyanto, I. (2015). Analisis Perbedaan Hasil Tangkapan Berdasarkan Warna Lampu pada Alat Tangkap Bagan Apung dan Bagan Tancap di Perairan Muncar, Kabupaten Banyuwangi.
Journal of Fisheries Resources Utilization Management and Technology, 4(2), 93-101.

Gaol, J. L., Pasaribu, B. P., Manurung, D., \& Endriani, R. (2010). The Fluctuation Of Chlorophyll-A Concentration Derived From Satellite Imagery And Catch Of Oily Sardine (Sardinella Lemuru0) In Bali Strait. International Journal of Remote Sensing and Earth Sciences (IJReSES), 1(1).

Gordon, A. L. (2005). The indonesian seas. Oceanography, 18(4), 14.

Grunseich, G., Subrahmanyam, B., Murty, V. S. N., \& Giese, B. S. (2011). Sea surface salinity variability during the Indian Ocean Dipole and ENSO events in the tropical Indian Ocean. Journal of Geophysical Research: Oceans, 116(C11).

Hendiarti, N. (2016). Hubungan Antara Keberadaan Ikan Pelagis Dengan Fenomena Oseanografi Dan Perubahan Iklim Musiman Berdasarkan Analisis Data Penginderaan Jauh. Majalah Ilmiah Globë, 10(1).

Himelda, H., Wiyono, E. S., Purbayanto, A., \& Mustaruddin, M. (2013). Analisis Sumber Daya Perikanan Lemuru (Sardinella lemuru Bleeker 1853) di Selat Bali (Analysis of the Sardine Oil (Sardinella lemuru Bleeker 1853) Resources in Bali Strait). Marine Fisheries: Journal of Marine Fisheries Technology and Management, 2(2), 165-176.

NASA. (2018). About Moderate Resolution Imaging Spectroradiometer. URL. Diunduh pada 3 Maret 2018. (https://modis.gsfc.nasa.gov/about/index.php)

Priyono, B., Yunanto, A., \& Arief, T. (2008). Karakteristik oseanografi dalam kaitannya dengan kesuburan perairan di Selat Bali. Balai Penelitian dan Observasi Laut. Bali, 15.

Ridha, U., Hartoko, A., \& Muskanonfola, M. R. (2013). Analisa Sebaran Tangkapan Ikan Lemuru (Sardinella lemuru) Berdasarkan Data Satelit Suhu Permukaan Laut dan Klorofil-A di Perairan Selat Bali. Management of Aquatic Resources Journal, 2(4), 5360.

Rintaka, W.E., Susilo, E. \& Hastuti, A.W. (2015). Pengaruh In-Direct Upwelling Terhadap Jumlah Tangkapan Lemuru Di Perairan Selat Bali. In Prosiding Seminar Nasional Perikanan dan Kelautan V, Universitas Brawijaya.

Rizki, T. Y., Tito, C. K., \& Setiawan, A. (2015). Variasi pH di Perairan Indonesia. Bunga Rampai Oseanografi Operasional di Indonesia, Satu Dekade Balai Penelitian dan Observasi Laut, 26-36.

Rochyatun, E., Kaisupy, M. T., \& Rozak, A. (2010). Distribusi logam berat dalam air dan sedimen di perairan muara Sungai Cisadane. Makara Journal of Science, 10(1), $35-40$.

Rukminasari, N., Nadiarti, N., \& Awaluddin, K. (2014). Pengaruh Derajat Keasaman ( $\mathrm{PH})$ Air Laut terhadap Konsentrasi Kalsium dan Laju Pertumbuhan HALIMEDA SP. Jurnal Administrasi dan Kebijakan Kesehatan Indonesia, 24(1).

Safitri, M., \& Putri, M. R. (2013). Kondisi Keasaman (pH) 
Laut Indonesia. PROSIDING, 73.

Sartimbul, A., Nakata, H., Rohadi, E., Yusuf, B. \& Kadarisman, H.P., (2010). Variations in chlorophyll-a concentration and the impact on Sardinella lemuru catches in Bali Strait, Indonesia. Progress in Oceanography, 87(1-4), 168-174.

Sediadi, A. (2010). Effek Upwelling Terhadap Kelimpahan dan distribusi fitoplankton di perairan laut banda dan sekitarnya. Makara Journal of Science, 8(2), 43-51.

Setyohadi, D. (2012). Pola Distribusi Suhu Permukaan Laut Dihubungkan dengan Kepadatan dan Sebaran Ikan Lemuru (Sardinella lemuru) Hasil Tangkapan Purse Seine di Selat Bali. Indonesian Journal of Environment and Sustainable Development, 1(2), 119-123.

Susilo, E. (2015). Variabilitas faktor lingkungan pada habitat ikan lemuru di Selat Bali menggunakan data satelit oseanografi dan pengukuran insitu. Omni Akuatika, 14(20), 13-22. 